\title{
KARAKTERISASI POPULASI C8 HASIL SELEKSI MASSA JAGUNG (Zeamays L. var ceratina) KETAN LOKAL BIMA
}

\section{CHARACTERIZATION OF C8 POPULATION RESULT FROM MASS SELECTION OF GLUTINOUS CORN (Zea mays L. var certina) LOCAL BIMA}

\author{
Alviana Itriyani Andriastuti ${ }^{1 *}$, Uyek Malik Yakop ${ }^{2}$, Lestari Ujianto ${ }^{3}$ \\ ${ }^{1,2,3}$ Program Studi Agroekoteknologi, Universitas Mataram, Maram, Indonesia. \\ *Email Penulis Korespondensi: alviananona@gmail.com
}

\begin{abstract}
ABSTRAK
Penelitian ini bertujuan untuk mengetahui keunggulan karakter kuantitatif dari populasi C8 hasil seleksi massa Jagung lokal ketan Bima terhadap C0 dan varietas unggul Anoman. Penelitian ini dilakukan pada bulan Desember 2019 sampai Maret 2020 di Desa Mambalan, Sayang-Sayang, Kabupaten Lombok Barat, Nusa Tenggara Barat. Rancangan yang digunakan adalah Rancangan Acak Kelompok (RAK) dengan 3 perlakuan dan diulang sebanyak 8 kali sehingga didapatkan 24 unit percobaan. Data dianalisis dengan analis is keragaman pada taraf nyata $5 \%$. Jika terdapat perlakuan yang berbeda nyata maka dilanjutkan dengan uji lanjut Duncan Multiple Range (DMRT) 5\%. Perlakuan yang digunakan merupakan genotipe populasi siklus kedelapan hasil seleksi massa $(\mathrm{C} 8)$, populasi awal $(\mathrm{C} 0)$, dan populasi varietas unggul bersari bebas Anoman. Hasil penelit ian menunjukkan bahwa karakter kuantitatif pada populasi C8 lebih baik secara umum dibandingkan dengan populasi tetuanya C0 yang ditunjukkan oleh sifat tinggi tanaman, diameter batang, bobot tongkol kering per tanaman, bobot biji kering pipil per tanaman, dan bobot 100 biji yang meningkat secara nyata. Pada populasi C8, karakter kuantitatif bobot biji kering pipil per tanaman sebesar 76,74 g/tanaman atau setara dengan 4,39 ton/ha mengala mi peningkatan daya hasil yang tinggi, tidak berbeda nyata dengan varietas unggul Anoman.

Kata kunci :Sifat Kuantitatif, Jagung Ketan, karakterisasi
\end{abstract}

\begin{abstract}
ABSTRACK
The purpose of this study was to determine the superiority of the quantita $t$ ive character of the C8 population from the mass selection of local sticky corn Bima against $\mathrm{C} 0$ and the superior variety Anoman. This research was conducted from December 2019 to March 20202 at Mambalan Village, Sayang-Sayang, West Lombok Regency, West Nusa Tenggara. The design used was a randomized block design (RBD) with 3 treatments and repeated 8 times so there were 24 experimental units. Data were analyzed by analysis of variance at the $5 \%$ significance level. If there is a significantly different of the treatment, Duncan Multiple Range (DMRT). The treatments used were the genotype population of the eighth cycle of mass selection (C8), the initial population (C0), and the Anoman population. The results showed that the quantitative characters in the $\mathrm{C} 8$ population were generally better than the parent population $\mathrm{C} 0$ which was shown by the characteristics of plant height, stem diameter, ear dry weight per plant, dry seed weight per plant, and weight of 100 seeds which increased significantly. In a population of C8, the quantitative character of the weight of dry seeds per plant was 76,74 g / plant or equivalent to 4,39 tonnes / ha showing increased of yield. Not significantly different from the superior variety Anoman. Keywords: Quantitative Traits, Sticky Corn, Characterization
\end{abstract}

Andriastuti, A.I., Yakop, U.M., dan Ujianto, L. 


\section{PENDAHULUAN}

Jenis tanaman jagung yang dibudidayakan di Nusa Tenggara Barat (NTB) beragam, salah satunya yaitu tanaman Jagung Ketan atau jagung pulut yang berbiji putih. Jagung Ketan yang banyak ditanam di NTB adalah jenis lokal yang berasal dari Sumbawa dan Bima sehingga banyak dikenal sebagai Jagung Ketan lokal Bima. Jagung ini cukup disenangi oleh konsumen karena rasanya pulen. Namun demikian, produksinya masih rendah yaitu (3,18 ton/ha) pipilan kering (Idris et al., 2006).

Total kebutuhan jagung untuk industri sebesar 30.000.000 ton dengan rincian sebagai berikut: (1) industri pakan pada Tahun 2018 adalah sebesar 8.300 .000 ton, (2) industri pati jagung dan sweetener sebesar 760.000 ton, (3) industri corn grits dan tepung jagung sebesar ton dan (4) industri snack sebesar 1.000.000 ton (Badan Ketahanan Pangan Kementan, 2018). Untuk dapat meningkatkan produksi jagung ketan, berbagai cara telah dilakukan diantaranya adalah dengan memperbaiki karakter yang umumnya dilakukan melalui upaya salah satu kegiatan pemuliaan tanaman. Kegiatan seleksi pada tanaman jagung merupakan metode yang banyak dilakukan dalam peningkatan perbaikan tanaman dalam rangka memperoleh benih yang bermutu. Salah satu jenis seleksi yang umum digunakan untuk memperbaiki karakter tanaman jagung adalah seleksi massa yang merupakan salah satu metode seleksi yang tertua yang digunakan untuk memilih bahan tanam yang lebih baik pada generasi berikut atau keturunannya.

Pengujian terhadap tanaman hasil seleksi mutlak dilakukan untuk mengetahui adanya kemajuan karakter populasi tanaman yang telah diseleksi. Salah satu pengujian yang harus dilakukan yaitu karakterisasi atau uji keuggulan karakter. Karakterisasi merupakan salah satu dari tahapan kegiatan program pemuliaan yang sangat penting dalam pembentukan varietas unggul yang memliki tujuan untuk mengetahui karakter-karakter penting yang bernilai ekonomis dan sebagai penciri dari varietas yang bersangkutan (Siswati et al., 2015). Uji keunggulan karakter ini dilakukan untuk mengetahui adanya keunggulan karakter kuantitaf maupun kualitatif pada tanaman hasil seleksi. Karakter kuantitatif adalah sifat yang tampak dan tidak dapat diamati dengan mata telanjang, tetapi dapat diukur dengan satuan tertentu, dikenal pula sebagai sifat rumit (complex trait) dan dibatasi sebagai sifat pada organisme yang tidak dapat dipisahkan secara jelas variasinya (Mustofa, et al.2013).

Pada penelitian sebelumnya populasi C7 jagung diketahui bahwa karakter kuantitatif dari sifat tinggi tanaman, jumlah daun, diameter batang, panjang tongkol, dan diameter tongkol memiliki sifat yang berbeda nyata dengan varietas Anoman dan tetuanya namun untuk sifat berat biji kering pipil pertongkol memiliki sifat yang tidak berbeda nyata dengan varietas Anoman dan tetuanya. Pada penelitian ini uji keunggulan karakter kuantitatif telah dilakukan terhadap C8 Jagung Ketan Lokal Bima dengan membandingkan karakter yang sama terhadap populasi tetuanya ( $\mathrm{C} 0$ ) dan Varietas unggul bersari bebas, Anoman. Tujuan dari penelitian ini adalah untuk mengetahui keunggulan karakter kuantitatif dari populasi C8 hasil seleksi massa Jagung lokal ketan Bima terhadap C0 dan varietas unggul Anoman.

\section{METODE PENELITIAN}

Percobaan ini telah dilaksanakan di Desa Mambalan, Sayang-Sayang, Kabupaten Lombok Barat. Percobaan dilaksanakan dari bulan Desember 2019 sampai dengan bulan Maret 2020. Bahan yang digunakan dalam percobaan ini adalah benih jagung populasi genotip C8 jagung ketan lokal Bima, populasi genotip C0 jagung lokal ketan Bima, dan 
populasi genotipe unggul bersari bebas (Anoman). Tali rapia, bambu, pupuk urea, pupuk phonska, pestisida jenis Furadan, dan Matador.

Rancangan percobaan yang digunakan adalah Rancangan Acak Kelompok dengan jumlah perlakuan 3 dan setiap perlakuan diulang 8 kali, sehingga diperoleh 24 unit percobaan. Adapun perlakuan tersebut meliputi :

$\mathrm{G} 1$ = Populasi awal $(\mathrm{C} 0)$

$\mathrm{G} 2=$ Populasi siklus ke delapan $(\mathrm{C} 8)$

G3 = Varietas unggul bersari bebas Anoman

Pengolahan tanah yang dilakukan pertama kali yaitu membersihkan lahan, kemudian tanah dibalik dan dihamburkan menggunakan cangkul. Setelah tanah diratakan selanjut nya dilakukan pembuatan blok dan pembuatan plot. Dalam petak pengujian dibagi 8 blok, masing- masing blok terdapat 3 plot, yang merupakan perlakuan, satu plot terdapat tiga baris dan masing- masing baris terdapat 10 tanaman sehingga jumlah seluruh tanaman dalam satu plot berjumlah 30 tanaman. Ukuran tiap plot adalah panjang 2,5 $\mathrm{m}$ x lebar 2 $\mathrm{m}$, jarak antar plot $50 \mathrm{~cm}$, sedang jarak antar blok adalah $1 \mathrm{~m}$.

Benih yang digunakan dalam percobaan ini berasal dari koleksi di Minat Pemuliaa $n$ Tanaman, Fakultas Pertanian, merupakan benih jagung Lokal Bima sebagai Populasi awal (C0), Populasi hasil seleksi massa siklus ke delapan (C8), Varietas unggul Anoman. Jarak tanam yang digunakan adalah $25 \times 70 \mathrm{~cm}$. Pembuatan lubang tanam dan lubang untuk pupuk dilakukan dengan menggunakan tugal dan ditugal sedalam sekitar $5 \mathrm{~cm}$. Jumlah benih per lubang sebanyak 2 biji, kemudian ditutup dengan tanah. Pemupukan dilakukan dengan memberikan pupuk phonska dengan dosis $200 \mathrm{~kg} / \mathrm{ha}$ dan urea dengan dosis $300 \mathrm{~kg} / \mathrm{ha}$ yang diberikan 2 kali. Pemupukan pertama diberikan saat tanam, yaitu semua dosis Phonska dicampur dengan setengah dosis Urea $(150 \mathrm{~kg} / \mathrm{ha})$ di letakkan dilubang yang sudah disediakan di samping tanaman kemudian ditutp dengan tanah. Pemupukan kedua dilakukan pada umur 16 hari setelah tanam yaitu sisa setengah dosis Urea sebanyak $150 \mathrm{~kg} / \mathrm{ha}$. Pupuk diberikan dengan cara ditugal kedalaman $5 \mathrm{~cm}$, kemudian dilakukan pembumbunan.

Pengendalian hama dan penyakit dilakukan saat pembenihan tanaman yaitu dengan menggunakan Furadan 3G yang diberikan pada lubang tanam pada saat tanam. Pada umur 16 hst diberikan pestisida jenis Matador untuk menggurangi intensitas dari serangan hama belalang. Pada umur 57, 60, dan 63 hari dilakukan penyemprotan pestisida Matador dikarenakan banyaknya serangan hama belalang dan ulat.

Variabel yang diamati yaitu Tinggi tanaman (cm), Jumlah daun (helai), Diameter batang, Panjang tongkol $(\mathrm{cm})$, diameter tongkol $(\mathrm{cm})$, Bobot tongkol kering panen per tanaman (g), Daya hasil (Bobot biji kering pipil per tanaman (kg), Bobot 100 biji (g). Data hasil percobaan dianalisa menggunakan analisis keragaman (Analysis of Variance) pada taraf nyata $5 \%$. Jika perlakuan pada beberapa genotipe menunjukkan berbeda nyata maka di uji lanjut dengan DMRT (Duncan Multiple Range Test).

\section{HASIL DAN PEMBAHASAN}

Dari hasil analisis keragaman yang menggunakan taraf nyata 5\% menujukkan bahwa pada populasi tanaman jagung memberikan adanya pengaruh yang nyata pada beberapa sifat yaitu sifat tinggi tanaman, diameter batang, bobot kering per tanaman, bobot bij kering pipil per tanaman, dan bobot 100 biji. Selain itu, terdapat pengaruh tidak berbeda nyata yang terjadi pada beberapa sifat yaitu sifat jumlah daun, panjang tongol, dan diameter tongkol (Tabel 1) 
Tabel 1. Rangkuman Hasil Analisis Keragaman Populasi Jagung Ketan Lokal Bima Seleksi Massa

\begin{tabular}{lll}
\hline No & Sifat yang diamati & $\begin{array}{l}\text { Taraf Nyata } \\
5 \%\end{array}$ \\
\hline 1 & Tinggi Tanaman (cm) & $\mathrm{S}$ \\
2 & Jumah daun (helai) & $\mathrm{N} \mathrm{S}$ \\
3 & Diameter batang (cm) & $\mathrm{S}$ \\
4 & Panjang tongkol (cm) & $\mathrm{N} \mathrm{S}$ \\
5 & Diameter tongkol (cm) & $\mathrm{N} \mathrm{S}$ \\
6 & Bobot tongkol kering per tanaman $(\mathrm{g})$ & $\mathrm{S}$ \\
7 & Bobot biji kering pipil per tanaman $(\mathrm{g})$ & $\mathrm{S}$ \\
8 & Bobot 100 biji (g) & $\mathrm{S}$ \\
\hline
\end{tabular}

Keterangan : NS = tidak berbeda nyata

pada taraf nyata $5 \% \mathrm{~S}=$ berbeda

nyata pada taraf nyata $5 \%$

Rekapitulasi rerata hasil uji lanjut uji DMRT menunjukan adanya keragaman dari tiap populasi. Untuk sebagian besar karakter atau sifat yang diamati pada tiap perlakuan, terdapat kecendrungan perbaikan untuk sifat yang telah diamati dengan adanya seleksi kecuali untuk jumlah daun, panjang tongkol, dan diameter tongkol (Tabel 2).

Tabel 2. Nilai Rata-rata dan Hasil Uji Lanjut DMRT

\begin{tabular}{cllllllll}
\hline Perlakuan & TT & DB & JD & PT & DT & BTKT & BBKPT & B100 \\
\hline C0 & 176,0 a & 2,062 a & 4,333 & 9,583 & 13,98 & 99,16 a & 53,71 a & $25,46 \mathrm{a}$ \\
C8 & 182,9 b & 2,250 b & 4,594 & 9,708 & 14,13 & 115,41 a & 76,74 b & $28,59 \mathrm{~b}$ \\
A & 189,8 c & 2,400 c & 4,736 & 10,042 & 14,45 & 143,69 b & 87,55 b & $27,45 \mathrm{ab}$ \\
\hline
\end{tabular}

Keterangan : angka-angka yang sama dan diikuti oleh huruf yang sama tidak berbeda nyata dengan uji lanjut DMRT $5 \%$; TT $=$ Tinggi tanaman $(\mathrm{cm}), \mathrm{DB}=$

Diameter batang $(\mathrm{cm}) ; \mathrm{JD}=$ Jumlah daun (helai) $; \mathrm{PT}=$ Panjang tongkol $(\mathrm{cm})$;

DT $=$ Diameter Tongkol $(\mathrm{cm}) ;$ BTKT $=$ Bobot tongkol kering per tanaman $(\mathrm{g})$;

BBKPT $=$ Bobot biji kering pipil per tanaman $(\mathrm{g}) ; \mathrm{B} 100=$ Bobot 100 biji $(\mathrm{g})$;

$\mathrm{C} 0=$ populasi awal $; \mathrm{C} 8=$ populasi siklus kedelapan $; \mathrm{A}=$ populasi unggul bersari bebas.

Tinggi tanaman dan diameter batang C8 lebih tinggi dari C0 akan tetapi dibandingkan dengan varietas unggul Anoman (A) masih lebih rendah dapat dilihat pada (Tabel 2), sedangkan seleksi massa untuk karakter jumlah daun, panjang tongkol, dan diameter tongol tidak menunjukkan adanya peningkatan yang nyata.

Berdasarkan pada pengamatan bobot kering per tanaman yang terdapat pada table 4.2 menunjukkan peningkatan yang tidak berbeda nyata dari populasi $\mathrm{C} 0 \mathrm{ke} \mathrm{C} 8$. Populasi A merupakan populasi yang memiliki diameter batang lebih tinggi dibandingkan dengan populasi lainnya.

Adapun sifat bobot biji kering pipil per tanaman menunjukkan peningkatan yang nyata dari C8 ke C0 meskipun Anoman menunjukkan bobot yang sama dengan C8. Hal yang menarik terjadi pada sifat bobot biji kering pipil per tanaman dan bobot 100 biji, C8 lebih tinggi bobotnya dari pada $\mathrm{C} 0$ dan serupa dengan varietas unggul bersari bebas Anoman (Tabel 2). 
Hasil analisis keragaman pada taraf nyata 5\% didapatkan bahwa populasi C8 tanaman jagung lokal ketan Bima dibandingkan dengan tetuanya $\mathrm{C}$, memberikan perbaikan karakter yang nyata untuk tinggi tanaman, diameter batang, bobot biji kering per tanaman, bobot biji kering pipil per tanaman, dan bobot 100 biji. Hal ini disebabkan karena adanya keunggula $n$ karakter pada populasi C8 setelah mengalami seleksi hingga siklus ke 8 . Keunggula $n$ karakter ini diduga karena adanya faktor genetik. Hal ini sesuai dengan penelitian yang telah dilakukan sebelumnya oleh Feni (2019) yang menyatakan bahwa keunggulan karakter ini disebabkan karena adanya faktor genetik. Faktor genetik itu sendiri berasal dari beberapa gen yang mengendalikan karakter kuantitatif pada individu itu sendiri. Gen-gen tersebut bearasal dari tetua terdahulu yang dibawa oleh benih saat menyerbuk silang atau kemungkinan gen baru tercipta dari hasil seleksi massa yang telah terjadi.

Adanya keunggulan karakter yang terjadi pada populasi C8 dengan tetuanya populasi C0 dapat ditunjukkan dari peningkatan karakter untuk tinggi tanaman, diameter batang, bobot kering per tanaman, bobot biji pipil kering per tanaman, dan bobot 100 biji. Sedangkan sifat yang tidak mengalami peningkatan dari hasil uji karakter ini antara lain diameter tongkol, panjang tonggkol, dan jumlah daun. Karakter-karekter ini merupakan karakter kuantitat if. Karakter kuantitatif dipengaruhi oleh banyak gen atau poligenik gen. Hal ini sesuai dengan penelitian sebelumnya yang dilakukan oleh Harlin et al. (2014) disimpulkan bahwa pola pewarisan karakter kuantitaif pada tanaman jagung dikendalikan oleh gen-gen minor atau poligenik dan bersifat aditif.

Terdapat keragaman untuk tinggi tanaman pada semua populasi perlakuan. Populasi yang tertinggi adalah varietas Anoman karena memilki nilai rerata paling tinggi, yaitu 189,8 $\mathrm{cm}$ diikuti oleh populasi C8 senilai $182,9 \mathrm{~cm}$ sedangkan pada populasi $\mathrm{C} 0$ paling rendah senilai $176 \mathrm{~cm}$. Menurut Darmadi et al. (2016) jika terjadi peningkatan pada hasil tinggi tanaman akan memberikan pengaruh terhadap produksi buah pada tanaman jagung, dikarenakan semakin tinggi tanaman maka akan memiliki keunggulan dalam kompetisi mendapatkan cahaya matahari untuk berfotosintesis. Hal ini dapat dilihat dengan kesesuaianya dari hasil bobot biji kering pipil per tanaman yang juga akan semakin meningkat. Pada sifat diameter batang populasi $\mathrm{C} 0$ memiliki nilai rerata yang lebih rendah dibandingkan dengan populasi yang lainnya, yaitu dengan nilai $2,062 \mathrm{~cm}$. Sedangkan populasi Anoman memliki nilai yang tertiggi, yaitu $2,4 \mathrm{~cm}$, dan populasi $\mathrm{C} 8$ memliki nilai $2,25 \mathrm{~cm}$ yang mana mengalami peningkatan dibandingkan dengan populasi $\mathrm{C} 0$. Pada sifat ini semua populasi berbeda nyata dengan populasi yang lain, yang artinya sifat ini mengalami perbaikan pada populasi C8 ke C0 meskipun populasi Anoman memilki sifat yang paling baik.

Untuk bobot tongkol kering per tanaman menunjukkan sifat yang tidak berbeda nyata dari $\mathrm{C} 0$ ke $\mathrm{C} 8$, meskipun berat pipil kering dan 100 butir biji mengalami peningkatan yang signifikan. Dengan demikian dapat diduga komponen tongkol, seperti panjang, diameter, dan berat tongkol faktor yang mempengaruhinya adalah janggel bukan biji. Terbukti dari komponen biji seperti berat dan ukurannya terjadi peningkatan dari sebelum diseleksi hingga akhir seleksi (dari C0 ke C8).

Perbaikan genetik untuk daya hasil, yakni dari C0 hingga $\mathrm{C} 8$ yang ditunjukkan dengan bobot biji kering pipil pertanaman cukup menjanjikan, yaitu dari 53,71 g menjadi 76,74 g. Hal ini berarti ada peningkatan daya hasil $30 \%$. Data ini menunjukkan bahwa semakin tinggi tingkat siklus seleksi yang terjadi maka akan terjadi kecenderungan perbaikan sifat pada bobot biji kering pipil per tanaman pada generasi selanjutnya yaitu siklus kedelapan. Pola yang serupa terjadi pada bobot 100 biji. Setelah dilakukan seleksi selama delapan siklus bobot 100 biji C8 mengalami perbaikan genetik dengan populasi C0. Hal yang menarik adalah bahwa bobot biji kering pipil per tanaman dan bobot 100 biji C8 mengala 
mi peningkatan daya hasil yang sangat bagus karena tidak berbeda nyata dengan varietas unggul Anoman.

Dari data-data yang diperoleh dapat diketahui bahwa terdapat beberapa sifat yang telah megalami peningkatan genetik seiring dengan bertambahnya seleksi, yaitu tinggi tanaman, diameter batang, bobot tongkol kering per tanaman, bobot biji kering pipil per tanaman dan bobot 100 biji. Hal ini sesuai dengan penelitian yang telah dilakukan oleh Yeye et al. (2015) yang mengindikasikan bahwa gen-gen yang menguntungkan pada tetua terdahulu dapat berkontribusi terhadap ekspresi karakter-karakter tersebut.

Peningkatan sifat biasanya dapat dipengaruhi oleh dua faktor, yaitu genetik dan lingkungan. Pada sifat kuantitatif yang mengalami perbaikan terjadi karena sifat-sifat ini dikendalikan oleh banyak gen, sesuai dengan yang dikatakan oleh Bocianowski et al. (2016) karakter kuantitatif tanaman dikendalikan oleh banyak gen. Karakter kuantitat if dikendalikan oleh banyak gen dimana pengaruh masing- masing gen terhadap penampila $n$ karakter (fenotip) lebih kecil dan bersifat aditif. Gen-gen tersebut secara bersama-sama mempunyai pengaruh yang lebih besar dari pengaruh lingkungan. Gen-gen demikian disebut sebagai gen minor. Aksi gen minor ditentukan oleh bentuk interaksi yang terjadi baik interaksi antar alel pada lokus yang sama (Ye et al.2017).

Menurut Acquahh (2007) karakter kuantitatif dikendalikan secara poligenik sehingga seleksi akan efektif dilakukan pada generasi lanjut atau pada saat persentase homozigositasnya sudah tinggi untuk mendukung pengembangan varietas tanaman menyerbuk sendiri. Hal ini sesuai untuk tanaman jagung yang merupakan salah satu jenis tanaman menyerbuk sendiri. Seleksi bertujuan untuk memperoleh peningkatan frekuensi gen-gen yang diinginkan pada generasi berikutnya. Hal ini dapat menggambarka $n$ keunggulan individu- individu yang terpilih dibandingkan dengan populasi dasarnya (Roy. 2000).

\section{KESIMPULAN}

Dari hasil analisis data dan pembahasan maka dapat disimpulkan bahwa :

1. Karakter kuantitatif dari populasi C8 Jagung lokal ketan Bima lebih baik dibandingkan dengan tetuanya $\mathrm{C} 0$. Hal ini dapat dilihat dari hasil yang ditunjukkan pada beberapa karakter kuantitatif antara lain tinggi tanaman, diameter batang, bobot tongkol kering, bobot biji kering pipil per tanaman, dan bobot 100 biji yang berbeda nyata. Adapun pada sifat diameter tongkol, panjang tongkol, dan jumlah helai daun memberikan peningkatan yang tidak berbeda nyata.

2. Pada populasi C8 karaketer kuantitatif bobot biji kering pipil per tanaman sebesar $76,74 \mathrm{~g} /$ tanaman atau setara dengan 4,39 ton/ha mengalami peningkatan daya hasil yang tinggi, tidak berbeda nyata dengan varietas unggul Anoman.

\section{DAFTAR PUSTAKA}

Acquaah G. (2007). Principles of Plant Genetics and Breeding. United Kingdom(G B): Blackwell Publishing.

Badan Ketahanan Pangan Kementrian Pertanian RI. (2018). Buletin Harga dan Pasokan Pangan Edisi Maret 2018. ISSN : 2615-3807. Hal.4.

Bocianowski, J., Górczak, K., Nowosad, K., Rybiński, W., \& Piesik, D. (2016). Path analysis and estimation of additive and epistatic gene effects of barley SSD lines. Journal of Integrative Agriculture, 15(9), 1983-1990.

Darmadi D., Idri, dan Ujianto L. (2016). Evaluasi Perubahan Karakter Pada 
Keturunan Hasil Persilangan Jagung Ketan (Zea mays ceratina) dan Jagung Manis (Zea mays Sacharat). Crop Agro. 9. (1). Januari 2016.

Feni. (2019). Keragaman dan Korelasi Sifat Beberapa Populasi Jagung Ketan Lokal

Bima Hasil Seleksi Massa Dengan Pengendlian Penyerbukan. [Skripsi Sarjana, published]. Fakultas Pertanian Universitas Mataram. Nusa Tenggara Barat. Indonesia.

Harlin L. Y., Ujianto L., dan Abdurrahman H. (2014). Kajian Kemajuan Seleksi Hingga populasi F4 Hasil Persilangan Jagung Ketan dengan Jagung Manis. Crop Agro Vol. 9 No.2.

Idris, Sudika I. W., dan Ujianto L. (2006). Pendugaan Ragam Genetik Jagung Ketan Lokal Bima Sebagai Dasar Penentuan Metode Seleksi. Fakultas Pertanian Unram, Mataram.

Mary, Y. Y., Esther, I., Aba, D. A., \& Abdullahi, U. S. (2015). Inheritance of low phytate in africa biofortified sorghum. Academic Research International, 6(2), 55.

Mustofa, Z., Budiarsa I. M., dan G. B. N. Samdas. (2013). Variasi Genetik Jagung (Zea Mays L.) Berdasarkan Karakter Fenotipik Tongkol Jagung yang Dibudidaya di Desa Oge. e-Jipbiol 1:33-41

Roy, D. (2000). Plant Breeding: Analysis and exploitation of variation. Calcutta: Narosa Publishing House.

Siswati A., Basuki N., dan Sugiharto. A. N. (2015). Karakerisasi Beberapa Galur Inbrida Jagung Pakan (Zea mays l.). Jurnal Produksi Tanaman. 3. (11): 1926.

Ye, Y. J., Wu, J. Y., Feng, L., Ju, Y. Q., Cai, M., Cheng, T. R., ... \& Zhang, Q. X. (2017). Heritability and gene effects for plant architecture traits of crape myrtle using major gene plus polygene inheritance analysis. Scientia Horticulturae, 225, 335-342. 